\title{
Pengaruh Persepsi Kemudahan, Persepsi Manfaat, Persepsi Harga dan Pemasaran Internet Terhadap Pemesanan Ulang Online Hotel di Bali
}

\author{
Komang Agus Satria Pramudana ${ }^{1}$ \\ I Wayan Santika ${ }^{2}$ \\ Universitas Udayana, Bali Indonesia \\ agussatriapramudana@unud.ac.id
}

\begin{abstract}
Abstrak. Penelitian ini dilakukan dengan latar belakang niat beli ulang online yang rendah pada situs online yang sama, yang sering dijumpai pada belanja online sehingga membuat perusahaan online kesulitan dalam merealisasikan profitabilitas jangka panjang dan berkelanjutan. Penelitian ini bertujuan untuk mengetahui pengaruh persepsi kemudahan, persepsi manfaat, persepsi harga, dan pemasaran internet terhadap pemesanan ulang online pada situs e-commerce pemesanan kamar hotel di Bali. Penelitian ini dilakukan dengan pendekatan kuantitatif, baik deskriptif maupun asosiatif. Metode pengambilan sampel dalam penelitian ini adalah non probability sampling dengan teknik purposive sampling. Data dikumpulkan dari 120 responden yaitu pengguna e-commerce untuk pemesanan online kamar hotel di Bali. Hasil penelitian menunjukkan bahwa persepsi kemudahan berpengaruh positif dan signifikan terhadap pemesanan ulang online; persepsi manfaat berpengaruh positif dan signifikan terhadap pemesanan ulang online; persepsi harga berpengaruh positif dan signifikan terhadap pemesanan ulang online; dan pemasaran internet berpengaruh positif dan signifikan terhadap pemesanan ulang online.
\end{abstract}

Kata kunci: persepsi kemudahan, persepsi manfaat, persepsi harga, pemasaran internet, pemesanan ulang online

\begin{abstract}
This research is conducted against a background of low online repurchase intention on the same online site, which is often found in online shopping, making online companies difficult to realize long-term and sustainable profitability. This study aims to determine the influence of perceived ease of use, perceived usefulness, perception of price, and internet marketing on online re-booking hotels in Bali. This research is done by quantitative approach, both descriptive and associative. Sampling method in this research is non probability sampling with purposive sampling technique. Data were collected from 120 respondents i.e. e-commerce users for online booking of hotel rooms in Bali. The results showed that perceived ease of use have a positive and significant effect on online rebooking; perceived usefulness have a positive and significant impact on online re-booking; price perceptions have a positive and significant impact on online re-booking; and internet marketing have a positive and significant impact on online re-booking.
\end{abstract}

Key words: perceived ease of use, perceived usefulness, perception of price, internet marketing, online rebooking

\section{PENDAHULUAN}

Kemudahan mendapatkan informasi di internet membuatjumlah penggunainternet meningkat dengan cepat. Data internetworldstat (2016) menunjukkan jumlah pengguna internet di Indonesia mengalami peningkatan pesat dari 2 juta pada Tahun 2000 menjadi 78 juta pada Tahun 2015. Hal ini membuktikan semakin banyak masyarakat yang merasakan manfaat internet. Tingginya pertumbuhan pengguna internet 
adalah peluang bagi para pelaku bisnis untuk menawarkan produknya melalui internet. Hal ini lebih dikenal dengan istilah e-commerce. E-commerce adalah kegiatan melakukan transaksi bisnis secara online melalui media internet dan perangkat-perangkat yang terintegrasi dengan internet (Laudon, 2012). Di Indonesia, potensi pasar e-commerce terus mengalami perkembangan yaitu dari Rp. 8,325 trilyun pada Tahun 2011 meningkat menjadi Rp. 100 trilyun pada Tahun 2015 (BPS, 2015).

Berkembangnya penggunaan e-commerce juga terjadi pada industri pariwisata. Werthner dan Ricci (2004) mengemukakan bahwa sektor pariwisata merupakan pasar utama dalam e-commerce. Jumlah penjualan melalui e-commerce dalam industri pariwisata terus mengalami peningkatan terutama pemesanan online pada area transportasi, akomodasi, paket wisata, dan penawaran wisata lainnya (Gratzer et al. 2004). Sedangkan untuk informasi pariwisata, internet merupakan sumber utama untuk memperoleh informasi karena banyaknya jasa informasi pariwisata online. World Travel Trends (2012) dalam Viljoen (2016) menyatakan bahwa setengah dari pemesanan kamar hotel dan tiket pesawat adalah melalui internet (online booking), sepertiganya melalui agen perjalanan wisata (travel agent), dan sisanya melalui pembelian konvensional langsung ke hotel atau maskapai tujuan. Meskipun terjadi peningkatan pemesanan kamar hotel melalui internet, Ruiz-Mafe et al. (2009) menyatakan bahwa masih banyak konsumen yang menolak melakukan pembelian online karena adanya risiko privasi yang erat diasosiasikan dengan pembelian online.

Pembelian online (online booking) kamar hotel dapat dilakukan melalui situs e-commerce pada website resmi hotel atau melalui website pihak ketiga (third party). Beberapa situs e-commerce yang masuk kategori website pihak ketiga antara lain adalah Traveloka, Agoda, Pegipegi, Wego, Tiket.com, Booking.com, Trivago, TripAdvisor, dan Hotel.com, dimana situs online Traveloka adalah situs online travel paling populer di Indonesia (Nusaresearch, 2014).

Populernya suatu situs online salah satunya disebabkan oleh intensnya melakukan pemasaran internet (internet marketing). Pemasaran internet adalah semua strategi pemasaran yang digunakan pemasar melalui perantara perangkat elektronik (Heikkinen, 2012). Bentuk pemasaran internet biasanya diwujudkan dalam iklan banner online, sponsorship kegiatan online, pengklasifikasian daftar produk pada website, email marketing, pemasaran afiliasi, search engine marketing, dan social networking (Ahmadi, et al., 2013). Penelitian Heikkinen (2012) menyatakan bahwa pemasaran internet mempunyai pengaruh yang positif dan signifikan terhadap proses pengambilan keputusan pembelian pada turis wisata alam di Jerman. Demikian juga dengan hasil penelitian Apriliya (2013) yang menyatakan bahwa pemasaran internet (online marketing) berpengaruh positif dan signifikan terhadap keputusan pembelian melalui internet, dimana situs social networking (facebook) menjadi faktor dominan yang mempengaruhi pembelian online tersebut.

Dengan berbagai situs online yang tersedia dan berbagai keahlian pengguna, hal yang memotivasi pengguna untuk memilih salah satu situs online daripada situs yang lain mungkin adalah kemudahan pemakaian situs online tersebut. Apabila pengguna merasa bahwa suatu situs online lebih sulit digunakan, tidak dapat menemukan produk yang diinginkan, atau tidak mengerti mengenai apa yang ditawarkan oleh situs online tersebut, pengguna akan meninggalkan situs online tersebut (Pearson et al., 2007 dalam Lee et al., 2011). Oleh karena itu, apabila konsumen menganggap sebuah situs online mudah untuk digunakan, hal tersebut akan mempengaruhi intensi mereka untuk membeli kembali (Lee et al., 2011). Persepsi kemudahan (perceived ease of use) didefinisikan sebagai sejauh mana seseorang percaya bahwa menggunakan suatu teknologi akan bebas dari usaha (Davis et al., 1989). Jika seseorang merasa percaya bahwa sistem informasi pembelian online mudah digunakan, maka dia akan menggunakannya (Hartono, 2008). Hasil penelitian Juniwati (2015) menyatakan bahwa persepsi kemudahan berpengaruh positif dan signifikan terhadap pembelian ulang online.

Persepsi manfaat (perceived usefulness) didefinisikan sebagai sejauh mana konsumen yakin bahwa berbelanja online akan meningkatkan performa transaksinya (Chiu et al., 2009 dalam Lee et al., 2011). Menurut Chiu et al. (2009), seseorang cenderung meneruskan penggunaan teknologi belanja online apabila ia merasakan adanya manfaat. Pelanggan yang berbelanja produk secara efisien akan cenderung menunjukkan keinginan melakukan pembelian kembali yang lebih kuat (Chiu et al., 2009). Persepsi manfaat adalah salah satu penentu utama dari sikap terhadap penggunaan suatu teknologi (Davis et al., 1989). Persepsi manfaat merupakan penilaian sejauh mana pengguna yakin bahwa teknologi akan meningkatkan kinerja dari suatu kegiatan. Kucukusta 
(2014) menyatakan bahwa persepsi manfaat dan juga persepsi kemudahan merupakan prediktor yang kuat terhadap niat melakukan pemesanan online pada situs online travel di Hongkong. Juga dinyatakan bahwa persepsi manfaat lebih penting dibandingkan persepsi kemudahan bagi pengguna online travel di Hongkong. Hasil berbeda ditunjukkan oleh penelitian Oroh (2015) yang menyatakan bahwa persepsi manfaat dan persepsi kemudahan tidak berpengaruh signifikan terhadap pembelian ulang online tiket pesawat Lion.

Harga telah lama dianggap sebagai faktor kunci yang menentukan konsumen melakukan keputusan pembelian (Zeithaml, 1988). Hal ini benar terutama bila produk tersebut rendah sentuhan atau tidak mengalami sentuhan sama sekali. Ketika kualitas produk sama antar vendor, konsumen akan memusatkan perhatian terhadap minimisasi harga (Dodds et al., 1991). Dalam konteks belanja online, pengaruh dari harga menjadi semakin kuat karena konsumen dapat dengan mudah melakukan komparasi harga dari satu toko online dengan toko online lainnya (Kim et al., 2011). Namun demikian, penelitian Shankar et al. (2009) menekankan bahwa harga bukan faktor yang signifikan dalam belanja online, karena ketika situs online memiliki trust yang tinggi serta menyediakan informasi yang lengkap dan akurat, maka konsumen akan mengurangi kecenderungan menggunakan harga sebagai faktor utama dalam belanja online. Sedangkan Law (2006) menyatakan bahwa harga adalah tetap menjadi alasan utama mengapa konsumen melakukan belanja online, dan harga berpengaruh positif dan signifikan terhadap keinginan konsumen untuk berbelanja online (O'Connor, 2004). Konsumen juga cenderung mengunjungi beberapa situs online untuk memperoleh informasi dan melakukan komparasi harga sebelum memutuskan pembelian online karena harga yang ditawarkan secara online tidak konsisten (Law, 2006). Hal ini menunjukkan bahwa harga masih tetap menjadi pertimbangan utama dalam pembelian online.

Persepsi harga berkaitan dengan bagaimana informasi harga dipahami seutuhnya dan memberikan makna yang dalam oleh konsumen. Persepsi harga menjadi sebuah penilaian konsumen tentang perbandingan besarnya pengorbanan dengan apa yang akan didapatkan dari produk dan jasa (Zeithaml, 1988). Persepsi harga menjadi penilaian konsumen mengenai informasi harga yang diperoleh serta perbandingan besarnya pengorbanan konsumen berupa uang dengan apa yang akan didapatkan konsumen dari produk/jasa yang ditawarkan, sehingga saat mengukur persepsi harga, indikator yang digunakan adalah harga terjangkau, sesuai layanan yang akan diterima, sesuai fasilitas yang akan diterima, dan lebih murah dari pesaing. Hasil penelitian Nusarika (2015) menyatakan bahwa pesepsi harga berpengaruh positif dan signifikan terhadap niat beli online produk fashion di Kota Denpasar.

Berdasarkan latar belakang masalah dan hasil penelitian sebelumnya maka dilakukan penelitian untuk menganalisis pengaruh persepsi kemudahan, persepsi manfaat, persepsi harga, dan pemasaran internet terhadap pemesanan ulang online Hotel di Bali.

\section{KAJIAN PUSTAKA}

\section{E-commerce}

E-commerce merupakan konsep yang bisa digambarkan sebagai proses jual beli barang pada internet atau proses jual beli atau pertukaran produk, jasa, dan informasi melalui jaringan informasi termasuk internet (Turban et al, 2002). Menurut Laudon (2012), ecommerce adalah kegiatan melakukan transaksi bisnis secara online melalui media internet dan perangkat-perangkat yang terintegrasi dengan internet. E-commerce adalah kegiatan-kegiatan bisnis yang menyangkut konsumen, manufaktur, service provider dan pedagang perantara dengan menggunakan jaringan-jaringan komputer yaitu internet. Dapat disimpulkan bahwa pengertian dari e-commerce adalah segala bentuk transaksi perdagangan/ perniagaan barang atau jasa (trade of goods and service) dengan menggunakan media elektronik.

Penggolongan e-commerce yang lazim dilakukan adalah berdasarkan sifat transaksinya. Menurut M. Suyanto $(2003,30)$ tipe-tipe berikut segera bisa dibedakan: Business to Business (B2B), Business to Consumer (B2C), Consumer to Consumer (C2C), Consumer to Business (C2B), Non Business ecommerce, Intrabusiness (Organizational) ecommerce. E-commerce merupakan salah satu teknologi yang berkembang pesat dalam dunia internet. Penggunaannya dapat menguntungkan banyak pihak, baik pihak produsen, konsumen, distributor, pengiklan dan masyarakat luas.

\section{Persepsi Kemudahan}

Dalam Davis (1989), persepsi kemudahan (perceived ease of use) sebuah teknologi didefinisikan sebagai 
suatu ukuran dimana seseorang percaya bahwa komputer dapat dengan mudah dipahami dan digunakan. Definisi tersebut juga didukung oleh Wibowo (2006) yang menyatakan bahwa persepsi tentang kemudahan penggunaan sebuah teknologi didefinisikan sebagai suatu ukuran dimana seseorang percaya bahwa teknologi tersebut dapat dengan mudah dipahami dan digunakan. Davis et al. (1989), Davis (1993) dan Shun Wang et al. (2003) mendefinisikan persepsi kemudahan penggunaan sebagai ukuran dimana pengguna di masa yang akan datang mengganggap suatu sistem adalah bebas hambatan. Davis (1989) menyebutkan indikator yang digunakan untuk mengukur perceived ease of use yaitu mudah dipelajari, fleksibel, dapat mengontrol pekerjaan, serta mudah digunakan. Menurut Rigopoulos dan Askounis (2007), Gefen et al. (2003), serta Yahyapour (2008) perceived ease of use juga dapat diukur melalui indikator jelas dan mudah dimengerti, serta mudah dikuasai.

\section{Persepsi Manfaat}

Persepsi Manfaat (perceived usefulness) didefinisikan sebagai suatu ukuran dimana penggunaan suatu teknologi dipercaya akan mendatangkan manfaat bagi orang yang menggunakannya (Davis, 1989; Davis, 1993). Disebutkan pula pada Davis et al. (1989) persepsi terhadap kemanfaatan sebagai kemampuan subjektif pengguna di masa yang akan datang di mana dengan menggunakan sistem aplikasi yang spesifik akan meningkatkan kinerja dalam konteks organisasi. Hal serupa juga diungkapkan Shun Wang et al. (2003) bahwa persepsi kemanfaatan merupakan definisi dimana seseorang percaya dengan menggunakan suatu sistem dapat meningkatkan kinerja mereka. Davis (1989) mengkonsepkan bahwa perceived usefulness diukur melalui indikator seperti meningkatkan kinerja pekerjaan, menjadikan pekerjaan lebih mudah serta secara keseluruhan teknologi yang digunakan dirasakan bermanfaat. Dalam Gefen et al. (2003) dan Yahyapour (2008) ditambahkan bahwa perceived usefulness dapat diukur dengan indikator meningkatkan produktivitas, menjadikan kerja lebih efektif, dan pekerjaan menjadi lebih cepat.

\section{Persepsi Harga}

Harga telah lama dianggap sebagai faktor kunci yang menentukan konsumen melakukan keputusan pembelian (Zeithaml, 1988). Ketika kualitas produk sama antar vendor, konsumen akan memusatkan perhatian terhadap minimisasi harga (Dodds et al., 1991). Dalam konteks belanja online, pengaruh dari harga menjadi semakin kuat karena konsumen dapat dengan mudah melakukan komparasi harga dari satu toko online dengan toko online lainnya (Kim et al., 2011).

Persepsi harga (price perception) berkaitan dengan bagaimana informasi harga dipahami seutuhnya dan memberikan makna yang dalam oleh konsumen. Persepsi harga menjadi sebuah penilaian konsumen tentang perbandingan besarnya pengorbanan dengan apa yang akan didapatkan dari produk dan jasa (Zeithaml, 1988). Persepsi harga menjadi penilaian konsumen mengenai informasi harga yang diperoleh serta perbandingan besarnya pengorbanan konsumen berupa uang dengan apa yang akan didapatkan konsumen dari produk/jasa yang ditawarkan. Maka indikator yang diukur adalah: 1) harga terjangkau,2) sesuai layanan yang akan diterima, 3) sesuai fasilitas yang akan diterima, 4) lebih murah dari pesaing.

\section{Pemasaran Internet}

Pemasaran internet (internet marketing) adalah semua strategi pemasaran yang digunakan pemasar melalui perantara perangkat elektronik (Heikkinen, 2012). Pemasaran internet secara garis besar didominasi dengan berbagai kegiatan marketing dengan menggunakan peralatan elektronik dengan basis internet. Pemasaran internet perhotelan memanfaatkan internet untuk membangun hubungan yang lebih dekat dengan konsumen dan mitra bisnis. Seperti halnya pada penjualan produk barang melalui internet, pemasaran internet hotel dewasa ini semakin menunjukkan peran penting khususnya dalam hal pemesanan atau reservasi hotel (Yulianto, 2015). Pemasaran internet biasanya diwujudkan dalam iklan banner online, sponshorship kegiatan online, pengklasifikasian daftar produk pada website, email marketing, pemasaran metode afiliasi (partnership), searh engine marketing, dan social networking (Ahmadi, et al., 2013).

\section{METODOLOGI}

Dalam penelitian ini menganalisis hubungan antara persepsi kemudahan, persepsi manfaat, persepsi harga, dan pemasaran internet terhadap pemesanan ulang online. Berdasarkan konsep kerangka pemikiran yang menjelaskan keterkaitan masing-masing variabel, maka disusun kerangka konseptual seperti pada Gambar 1. 


\section{Hipotesis}

Beberapa tinjauan literatur menunjukkan bahwa Persepsi Kemudahan, Persepsi Manfaat, Persepsi harga, dan Pemasaran Internet masing-masing berpengaruh positif dan signifikan terhadapPembelian Ulang Online. Penelitian Heikkinen (2012) menyatakan bahwa pemasaran internet mempunyai pengaruh yang positif dan signifikan terhadap proses pengambilan keputusan pembelian pada turis wisata alam di Jerman. Demikian juga dengan hasil penelitian Apriliya (2013) yang menyatakan bahwa pemasaran internet (online marketing) berpengaruh positif dan signifikan terhadap keputusan pembelian melalui internet, dimana facebook menjadi faktor dominan yang mempengaruhi pembelian online tersebut. Hasil penelitian Juniwati (2015) menyatakan bahwa persepsi kemudahan berpengaruh positif dan signifikan terhadap pembelian ulang online. Demikian juga dengan hasil penelitian Kucukusta (2014) menyatakan bahwa persepsi kemudahan dan persepsi manfaat merupakan prediktor yang kuat terhadap intention to book online pada pengguna online travel di Hongkong. Juga dinyatakan bahwa persepsi manfaat lebih penting dibandingkan persepsi kemudahan bagi pengguna online travel di Hongkong. Hasil berbeda ditunjukkan oleh penelitian Oroh (2015) yang menyatakan bahwa persepsi manfaat dan persepsi kemudahan tidak berpengaruh signifikan terhadap pembelian ulang online tiket pesawat Lion.

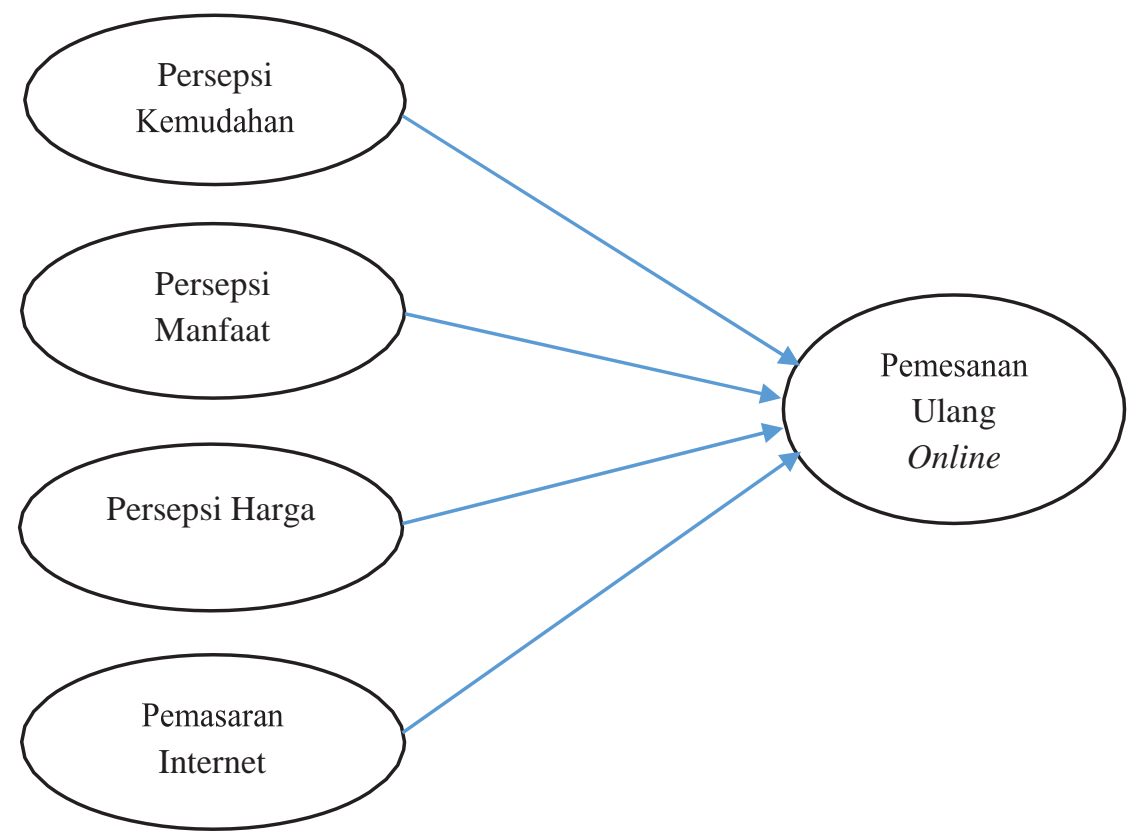

Gambar 1.

Kerangka Konsep Penelitian

Sumber: Davis (1993), Zeithaml (1988), Ahmadi

et al. (2013), Kotler \& Keller (2012)

Hasil penelitian Nusarika (2015) menyatakan bahwa persepsi harga berpengaruh positif dan signifikan terhadap niat beli online produk fashion di Kota Denpasar. Sedangkan hasil penelitian Shankar et al. (1999) menekankan bahwa harga bukan faktor yang signifikan dalam belanja online, karena ketika situs online memiliki trust yang tinggi serta menyediakan informasi yang lengkap dan akurat, maka konsumen akan mengurangi kecenderungan menggunakan harga sebagai faktor utama dalam 
Komang Agus Satria Pramudana, dan I Wayan Santika. Pengaruh Persepsi Kemudahan, Persepsi Manfaat... bahwa harga adalah tetap menjadi alasan utama mengapa konsumen melakukan belanja online, dan harga berpengaruh signifikan dalam menstimulus keinginan konsumen untuk berbelanja online (O'Connor, 2004).

Berdasarkan kajian empiris sebelumnya, maka dapat disusun hipotesis sebagai berikut: H1: Persepsi kemudahan berpengaruh positif dan signifikan terhadap pemesanan ulang online Hotel di Bali; H2: Persepsi manfaat berpengaruh positif dan signifikan terhadap pemesanan ulang online Hotel di Bali; H3: Persepsi harga berpengaruh positif dan signifikan terhadap pemesanan ulang online Hotel di Bali; H4: Pemasaran internet berpengaruh positif dan signifikan terhadap pemesanan ulang online Hotel di Bali.

Rescoe (dalam Sekaran 2006:160) menjelaskan 
ukuran sampel yang baik yakni sampel lebih dari 30 dan kurang dari 500 dan 5 - 10 kali jumlah variabel atau indikator dalam penelitian. Penelitian ini menggunakan 20 indikator sehingga dengan menggunakan estimasi berdasarkan jumlah parameter diperoleh ukuran sampel sebesar 100-200 responden. Jumlah sampel yang digunakan dalam penelitian ini adalah 120 responden. Dengan cara tersebut diharapkan seluruh sampel representatif untuk mewakili populasi pengguna e-commerce pemesanan online kamar hotel di Bali.

Teknik pengambilan sampel yang digunakan adalah nonprobability sampling yaitu teknik pengambilan sampel yang tidak memberikan peluang atau kesempatan sama bagi setiap unsur atau anggota populasi untuk dipilih menjadi sampel (Sugiyono, 2014). Teknik sampel yang digunakan adalah teknik purposive sampling dan incidental sampling. Purposive sampling merupakan teknik penentuan sampel dengan pertimbangan tertentu dimana peneliti harus benar-benar mengetahui dan beranggapan bahwa responden yang dipilihnya dapat memberikan informasi sesuai dengan masalah yang diteliti. Incidental sampling merupakan teknik penentuan sampel berdasarkan kebetulan, yaitu siapa saja yang bertemu secara kebetulan dengan peneliti akan dijadikan sampel. Teknik ini dipilih karena populasi yang tidak jelas dan tidak pasti. Kriteria dalam purposive sampling yang dimaksud, yaitu responden sudah pernah melakukan transaksi pemesanan secara online kamar hotel di Bali.

Tabel 1. Variabel dan indikator penelitian

\begin{tabular}{|c|c|c|}
\hline Variabel & Indikator & Sumber \\
\hline Persepsi kemudahan $\left(\mathrm{X}_{1}\right)$ & $\begin{array}{ll}- & \text { Mudah dimengerti }\left(\mathrm{X}_{1.1}\right) \\
\text { - } & \text { Tidak menyita waktu }\left(\mathrm{X}_{1.2}\right) \\
\text { - } & \text { Mudah digunakan }\left(\mathrm{X}_{1.3}\right. \\
\text { - } & \text { Fleksibel }\left(\mathrm{X}_{1.4}\right)\end{array}$ & Davis (1993) \\
\hline Persepsi manfaat $\left(\mathrm{X}_{2}\right)$ & $\begin{array}{ll} & \text { Pekerjaan lebih mudah }\left(\mathrm{X}_{2.1}\right) \\
\text { - } & \text { Bermanfaat }\left(\mathrm{X}_{2.2}\right) \\
\text { - } & \text { Lebih cepat }\left(\mathrm{X}_{2.3}\right. \\
\text { - } & \text { Lebih efisien }\left(\mathrm{X}_{2.4}\right)\end{array}$ & Davis (1993) \\
\hline Persepsi harga $\left(X_{3}\right)$ & $\begin{array}{l}\text { - } \quad \text { Harga terjangkau }\left(\mathrm{X}_{3.1}\right) \\
\text { - } \quad \text { Harga sesuai dengan kualitas layanan } \\
\left(\mathrm{X}_{3.2}\right) \\
{ }^{-} \quad \text { Harga sesuai dengan fasilitas }\left(\mathrm{X}_{3.3}\right) \\
\text { Lebih murah }\left(\mathrm{X}_{3.2}\right)\end{array}$ & Zeithaml (1988) \\
\hline $\begin{array}{l}\text { Pemasaran internet } \\
\left(\mathrm{X}_{4}\right)\end{array}$ & $\begin{array}{ll} & \text { Promosi online }\left(\mathrm{X}_{4 .}\right) \\
\text { - } & \text { Jejaring sosial }\left(\mathrm{X}_{4.2}\right. \\
\text { - } & \text { Situs pihak ketiga }\left(\mathrm{X}_{4.3}\right) \\
\text { - } & \text { Informasi melalui website }\left(\mathrm{X}_{4.4}\right)\end{array}$ & $\begin{array}{l}\text { (Ahmadi et al., } \\
\text { 2013) }\end{array}$ \\
\hline $\begin{array}{l}\text { Pemesanan ulang online } \\
\text { (Y) }\end{array}$ & $\begin{array}{ll}\text { - } & \text { Memilih cara pembelian online (Y1) } \\
\text { - } & \text { Sering menggunakan (Y2) } \\
\text { - } & \text { Merekomendasikan (Y3) } \\
\text { Menceritakan hal positif (Y4) }\end{array}$ & $\begin{array}{l}\text { (Kotler \& Keller, } \\
\text { 2012) }\end{array}$ \\
\hline
\end{tabular}

Sumber: Davis (1993), Zeithaml (1988), Ahmadi et al. (2013), Kotler \& Keller (2012)

\section{Metode Analisis Data}

Data yang diperoleh selama pengumpulan data di lapangan dianalisis dengan menggunakan statistik deskriptif dan statistik inferensial. Statistik deskriptif berupa distribusi frekuensi yang digunakan untuk menyajikan karakteristik responden, sedangkan statistikinferensial digunakan untuk menguji hipotesis yang dirumuskan.

Analisis deskriptif berfungsi untuk mendeskripsikan obyek yang diteliti melalui sampel atau populasi sebagaimana adanya tanpa melakukan analisis dan membuat kesimpulan yang berlaku untuk umum (Sugiyono, 2014: 239). Teknik analisis deskriptif bertujuan untuk mengetahui karakteristik dan tanggapan responden terhadap masing-masing pertanyaan yang diajukan.

Analisis regresi linear berganda adalah alat statistika yang tujuannya untuk membantu 
Komang Agus Satria Pramudana, dan I Wayan Santika. Pengaruh Persepsi Kemudahan, Persepsi Manfaat...

memperkirakan atau memprediksi nilai suatu variabel terikat dari beberapa variabel yang bebas. Apabila persamaan regresinya sudah diketahui, maka dengan memasukkan nilai variabel $\mathrm{X}$ pada persamaan regresi maka nilai variabel Y bisa diperkirakan. Persamaan umum regresi linear adalah:

$$
Y=\alpha+\beta_{1} X_{1}+\beta_{2} X_{2}+\ldots+\beta_{n} X_{n}+e
$$

Dimana: $Y$ adalah variabel terikat; $X$ adalah variabel bebas; $\alpha$ adalah konstanta; $\beta$ adalah koefisien regresi; $n$ adalah jumlah variabel bebas; $e$ adalah error term.

\section{HASIL DAN PEMBAHASAN}

Karakteristik responden dalam penelitian ini dilihat dari jenis kelamin, usia, pendidikan, situs pemesanan online yang digunakan, dan alat untuk mengakses situs pemesanan online. Seperti ditunjukkan oleh Tabel 2, persentase responden paling besar adalah wanita (57,5\%), berusia antara 26 sampai 35 tahun (55\%), dan dengan pendidikan terakhir SMA atau sederajat $(56,7 \%)$. Situs pemesanan online yang paling banyak digunakan adalah traveloka $(69,2 \%)$ sedangkan website resmi hotel digunakan oleh $2,5 \%$ responden saja. Alat yang digunakan untuk mengakses situs pemesanan online didominasi oleh smartphone yaitu sebanyak $71,7 \%$.

Tabel 2. Karakteristik responden

\begin{tabular}{|c|c|c|}
\hline No & Karakteristik & Keterangan \\
\hline 1 & $\begin{array}{l}\text { Situs pemesanan online yang digunakan } \\
\text { - Website resmi hotel } \\
\text { - Traveloka } \\
\text { - Agoda } \\
\text { - Airy rooms } \\
\text { - Booking.com } \\
\text { - Trivago }\end{array}$ & $\begin{array}{l}2,5 \% \\
69,2 \% \\
7,5 \% \\
5 \% \\
13,3 \% \\
2,5 \%\end{array}$ \\
\hline 2 & $\begin{aligned} & \text { Usia } \\
&- 17-25 \text { tahun } \\
&- 26-35 \text { tahun } \\
& \text { - } 36-45 \text { tahun } \\
& \text { - } 46-55 \text { tahun } \\
& \text { - } 56 \text { tahun ke atas } \\
&\end{aligned}$ & $\begin{array}{l}16,7 \% \\
55 \% \\
26,7 \% \\
0,8 \% \\
0,8 \%\end{array}$ \\
\hline 3 & $\begin{array}{cl}\text { Pendidikan terakhir } \\
\text { - } & \text { SMA/SMK } \\
\text { - } & \text { Sarjana }\end{array}$ & $\begin{array}{l}56,7 \% \\
43,3 \%\end{array}$ \\
\hline 4 & $\begin{array}{cl}\text { Jenis } & \text { Kelamin } \\
\text { - } & \text { Pria } \\
\text { - } & \text { Wanita }\end{array}$ & $\begin{array}{l}42,5 \% \\
57,5 \%\end{array}$ \\
\hline 5 & $\begin{array}{l}\text { Alat untuk mengakses situs pemesanan online } \\
\text { - Smartphone } \\
\text { - Tablet } \\
\text { - Laptop } \\
\text { - PC }\end{array}$ & $\begin{array}{l}71,7 \% \\
8,3 \% \\
15,8 \% \\
4,2 \%\end{array}$ \\
\hline
\end{tabular}

\section{Sumber: Data diolah, 2017}

\section{Analisis Regresi Linear}

Analisis regresi linear berganda diolah dengan program SPSS for Windows dengan variabel terikat Pemesanan Ulang Online (Y). Tabel 3 menunjukkan hasil analisis regresi linear berganda dengan variabel terikat Pemesanan Ulang Online (Y), sehingga 
ISSN: 2337-3067

E-Jurnal Ekonomi dan Bisnis Universitas Udayana 7.10(2018):2247-2256

$$
Y=0,257 X 1+0,264 X 2+0,162 X 3+0,222 X 4+e
$$

Hasil uji F menunjukkan bahwa nilai $\mathrm{F}_{\text {hitung }}$ sebesar 68,551 dengan signifikan $\mathrm{F}$ atau $\mathrm{P}$ value 0,000 kurang dari $\alpha=0,05$, ini berarti model yang digunakan adalah layak dan mampu memprediksi atau menjelaskan fenomena yang diteliti. Besarnya 
Adjusted $\mathrm{R}^{2}$ adalah sebesar 0,805 . Ini berarti variasi pemesanan ulang online dapat dijelaskan oleh variasi dari persepsi kemudahan, persepsi manfaat, persepsi harga, dan pemasaran internet sebesar 80,5 persen, sedangkan sisanya sebesar 19,5 persen dijelaskan oleh faktor-faktor lain di luar model.

\section{Tabel 3. Hasil signifikansi nilai thitung}

\begin{tabular}{|l|c|c|c|}
\hline \multicolumn{1}{|c|}{ Variabel } & Beta & \multicolumn{1}{c|}{ t } & \multicolumn{1}{c|}{ Sig. } \\
\hline Persepsi kemudahan & 0,257 & 2,208 & 0,029 \\
Persepsi manfaat & 0,264 & 2,145 & 0,034 \\
Persepsi harga & 0,162 & 1,983 & 0,050 \\
Pemasaran internet & 0,222 & 2,101 & 0,038 \\
\hline
\end{tabular}

Sumber: Data diolah, 2017

Berdasarkan Tabel 3, dapat dijelaskan hasil uji hipotesis pertama, kedua, ketiga, dan keempat adalah sebagai berikut:

1) Pembahasan Hipotesis 1

Pada Tabel 3 dapat dilihat bahwa tingkat signifikansi t uji dua sisi untuk variabel persepsi kemudahan sebesar 0,00 lebih kecil dari 0,05 dengan koefisien regresi positif 0,257. Ini menunjukkan bahwa Hipotesis 1 diterima, yang berarti bahwa persepsi kemudahan berpengaruh positif dan signifikan terhadap pemesanan ulang online. Pengaruh positif ini memberikan makna bahwa semakin baik persepsi pengguna tentang kemudahan penggunaan situs pemesanan online maka semakin meningkat niat melakukan pemesanan ulang online.

2) Pembahasan Hipotesis 2

Pada Tabel 3 dapat dilihat bahwa tingkat signifikansi t uji dua sisi untuk variabel persepsi manfaat sebesar 0,00 lebih kecil dari 0,05 dengan koefisien regresi positif 0,264 . Ini menunjukkan bahwa Hipotesis 2 diterima, yang berarti bahwa persepsi manfaat berpengaruh positif dan signifikan terhadap pemesanan ulang online. Pengaruh positif ini memberi makna bahwa semakin baik persepsi pengguna tentang manfaat penggunaan situs pemesanan online maka akan meningkatkan niat melakukan pemesanan ulang online.

3) Pembahasan Hipotesis 3

Pada Tabel 3 dapat dilihat bahwa tingkat signifikansi t uji dua sisi untuk variabel persepsi harga sebesar 0,00 lebih kecil dari 0,05 dengan koefisien regresi positif 0,162 . Ini menunjukkan bahwa Hipotesis 3 diterima, yang berarti bahwa persepsi harga berpengaruh positif dan signifikan terhadap pemesanan ulang online. Pengaruh positif ini memberikan makna bahwa semakin baik persepsi pengguna tentang harga pada pembelian online maka semakin meningkat niat melakukan pemesanan ulang online.

4) Pembahasan Hipotesis 4

Pada Tabel 3 dapat dilihat bahwa tingkat signifikansi t uji dua sisi untuk variabel pemasaran internet sebesar 0,00 lebih kecil dari 0,05 dengan koefisien regresi positif 0,222 . Ini menunjukkan bahwa Hipotesis 4 diterima, yang berarti bahwa pemasaran internet berpengaruh positif dan signifikan terhadap pemesanan ulang online. Pengaruh positif ini memberikan makna bahwa semakin tinggi intensitas pemasaran internet maka semakin meningkat niat melakukan pemesanan ulang online.

Hasil uji t juga menunjukkan bahwa variabel persepsi manfaat memiliki nilai unstrandardized paling besar dibandingkan variabel lain dalam model. Hal ini menunjukkan bahwa persepsi manfaat memiliki pengaruh paling besar terhadap pemesanan ulang online pada pengguna $e$ commerce pemesanan kamar hotel di Bali.

\section{SIMPULAN}

Simpulan penelitian ini berdasarkan hasil analisis data dan pembahasan yang telah dilakukan dapat dikemukakan sebagai berikut:

1) Persepsi kemudahan berpengaruh positif dan signifikan terhadap pemesanan ulang online. Semakin baik persepsi pengguna tentang kemudahan melakukan pemesanan online maka semakin meningkat niat melakukan pemesanan ulang online.

2) Persepsi manfaat berpengaruh positif dan signifikan terhadap pemesanan ulang online. Semakin baik persepsi pengguna tentang manfaat melakukan pemesanan online maka semakin meningkat niat melakukan pemesanan ulang online.

3) Persepsi hargaberpengaruh positif dan signifikan terhadap pemesanan ulang online. Semakin baik persepsi pengguna tentang harga pada pembelian online maka semakin meningkat niat melakukan 
pemesanan ulang online.

4) Pemasaran internet berpengaruh positif dan signifikan terhadap pemesanan ulang online. Semakin meningkat intensitas pemasaran internet maka semakin meningkat niat melakukan pemesanan ulang online.

\section{DAFTAR PUSTAKA}

1. Ahmadi, C. dan Hermawan, D. 2013. E-Busines \& E-Marketing. Yogyakarta: CV. Andi Offset.

2. Apriliya, Shinta. 2013. Analisis Strategi Online Marketing dan Pengaruhnya terhadap Purchase Intentions Konsumen Produk Clean \& Clear. Jurnal Ilmu \& Riset Manajemen. Vol. 2 No. 9 (2013) hal. 1-22.

3. BPS. 2015. Data Strategis BPS Katalog BPS: 1103003, CV. Nasional Indah.

4. Darwin, W. 2012. Majalah Marketeers Top 50 UKMdidunia online.http://the-marketeers.com/ archives/majalah-marketeers-top-50-UKM-didunia-online.html.

5. Davis, F.D. 1989. Perceived Usefulness, Perceived Ease of Use, and Acceptance of Information System Technology. Management Information Systems Quarterly, 13(3), pp: 319339.

6. Davis, F. 1993.'User Acceptance of Information Technology: Systems Characteristics, User Perception and behavioral Impacts. International Journal of Machine Studies 38, pp.475-487.

7. Dodds, W. B., Monroe, K. B., and Grewal, D. 1991. The Effects of Price, Brand and Store Information on Buyers' Product Evaluations. Journal of Marketing Research. 28, 3, 1991, pp.307-319.

8. Gefen, D., Karahanna, E., \& Straub, D. W. 2003. Trust and TAM in Online Shopping: An Integrated Model. MIS Quarterly, 27(1): 51-90.

9. Ghozali, I. and Fuad. 2005. Struktural Equation Modelling. Semarang: Badan Penerbit Universitas Diponegoro.

10. Gratzer, M., Werthner, H., Winiwarter, W. 2004. Electronic business in tourism. International $J$ Electron Bus. 2(5). Pp. 450-459.

11. Heikkinen, H. 2012. Social Media and Internet Marketing's Influence on Decision Making Process of German Nature Tourists. 4(1). pp. 1-8.

12. Hellier, P. K., Geursen, G. M., Carr, R. A., \& Rickard, J. A. 2003. Consumer Repurchase Intention: A general Structural Equation Model.
European Journal of Marketing, 1762-1800.

13. Infokomputer. 2015. Menguak Peluang Bisnis Online Travel dari Traveloka dan Tiket.com. http://www.infokomputer.com/2015. Diakses 30 Agustus 2016.

14. Internetworldstats. 2016. Asia Internet Use / Population Data and Facebook Statistics. 28 Juni 2016. Http://www.internetworldstats.com/stat3. htm

15. Juniwati. 2015. Pengaruh Perceived Ease of Use, Enjoyment dan Trust Terhadap Repurchase Intention dengan Customer Satisfaction Sebagai Intervening pada Belanja Online. Jurnal Ekonomi Bisnis dan Kewirausahaan. Vol. 4, No. 1, hal. 140-156.

16. Kemenkeu.go.id. 2014. Menyasar pajak transaksi e-commerce. 9 Juni 2014. http://www.kemenkeu. go.id/Artikel/menyasar-pajak-transaksi-ecommerce.

17. Kim, C., Tao, W., Shin, N., and Kim, K.S. 2010. An Empirical Study of Customers' Perceptions of Security and Trust in E-Payment Systems. Electronic Commerce Research and Applications, 9, 1, 2010. pp. 84-95.

18. Kim, H. W., Yunjie Xu, and Sumeet Gupta. 2011. Which is More Important in Internet hopping, Perceived Price or Trust? Electronic Commerce Research and Applications, doi: 10.1016/jelerap. 2011.06.003.

19. Kotler, P.dan Amstrong, G. 2008. Prinsip-prinsip Pemasaran 1. Edisi keduabelas. Jakarta: Erlangga.

20. Kotler, P. \& Keller K. 2012. Marketing Management, 12 ed., New Jersey: Pearson Education.

21. Kucukusta, D., Law, R., Besbes, B., dan Legohérel, P. 2014. Re-examining perceived usefulness and ease of use in online booking the case of Hong Kong online users. International Journal of Contemporary Hospitality Management. Vol. 27 No. 2, 2015. pp. 185-198.

22. Latan, Hengky. 2012. Structural Equation Modeling: Konsep dan Aplikasi Program Lisrel 8.80. Bandung: Alfabeta

23. Laudon, K.C. dan Traver, C.G. 2012. E-commerce 8th. United States of America: Pearson Education.

24. Law R. \& Hsu C., 2006. Importance of Hotel Website Dimensions and Attributes: Perceptions of Online Browsers and Online Purchasers. Journal of Hospitality and Tourism Research, 2006, Vol. 30(3), pp. 295-312.

25. Lee, C.H., Eze, U.C., dan Ndubisi, N.O. 2011. 
Komang Agus Satria Pramudana, dan I Wayan Santika. Pengaruh Persepsi Kemudahan, Persepsi Manfaat...

Analyzing key determinants of online repurchase intentions. Asia Pasific Journal of Marketing and Logistics. Vol 23 (2). Hal 200-221.

26. Nugroho, Agus. 2005. Strategi Jitu: Memilih Metode Statistik Penelitian dengan SPSS. Yogyakarta: Andi.

27. Nusaresearch. 2014. Online hotel and Tiket Booking Sites in Indonesia. Omnibus popular brand index 2014. Diakses 30 Agustus 2016.

28. Nusarika, L.A.K. 2015. Pengaruh persepsi harga, kepercayaan, dan orientasi belanja terhadap niat beli secara online. E-Jurnal Manajemen Unud, Vol. 4, No. 8, 2015: hal. 2380-2406.

29. O'Connor P. \& Frew A. J. 2004. An Evaluation Methodology for Hotel Electronic Channels of Distribution. International Journal of Hospitality Management. Vol. 23(2). pp. 179-199.

30. Oroh, C.R., Rumokoy, F.S. 2015. The influence of perceived ease of use, perceived usefulness and trust on repurchase intention of Lion Air eticket. Jurnal EMBA. Vol.3 No.3 Sept. 2015, Hal.950-958.

31. Ruiz-Mafé, C. 2009. Drivers and barriers to online airline ticket purchasing. Journal of Air Transport Management. Vol. 15 No. 6, pp. 294298.

32. Shankar V., Rangaswamy A. \& Pusateri M. 2009. The Online Medium and Customer Price Sensitivity. EBusiness Research Center: University Park.

33. Sobel, M.E. 1982. Asymptotic Confidence Intervals for Indirect Effects in Structural Equation Models. In S Leinhardt (Ed.), Sociological Methodology 1982 Washington, DC: American Sociological Association, h: 290312.

34. Sugiyono. 2014. Memahami Penelitian Bisnis (Pendekatan Kuantitatif, Kualitatif dan R\&D). Bandung: Alfabeta.

35. Suyana, Utama. 2009. Buku Ajar, Aplikasi Analisis Kuantitatif. Denpasar : Sastra Utama.

36. Todaro, Miguel. 2007. Internet Marketing Method Revealed. USA: Atlantic Publishing Group Inc.

37. Turban, Efraim; King, David; Lee, Jae; Warkentin, Merrill; Chung, H. Michael. (2002). Electronic Commerce: A Managerial Perspective (International Edition), p. 4.

38. Viljoen, K. dan Roberts-Lombard, M. 2016. Customer Retention Strategies for Disintermediated Travel Agents: How to Stop Customers from Migrating To Online Booking Channels. The Journal of Applied Business Research. March/April 2016. Volume 32, Number 2 pp.541-554.

39. Wen, Ivan. 2009. Factors affecting the online travel buying decision: a review. International Journal of Contemporary Hospitality Management. Vol. 21 No. 6, 2009. pp.752-765.

40. Werthner, H., Ricci, F. 2004. E-commerce and tourism. Commun ACM 47(12):101-105.

41. Yahyapour, N. 2008. Determining Factors Affecting Intention to Adopt Banking Recommender System, Case of Iran. Thesis. Sweden: Lulea University of Technology.

42. Yulianto, A. 2015. Kajian internet marketing sebagai salah satu media pemasaran industri perhotelan. Jurnal Khasanah Ilmu. Vol. VI No. 1 Maret 2015. Hal. 65-78.

43. Zeithaml, V. A. 1988. Customer Perceptions of Price, Quality, and Value: A Means-End Model and Synthesis of Evidence. Journal of Marketing. Vol. 52 (July 1988). pp. 2-22. 